\title{
UJI IN VITRO ANTIBAKTERI MINYAK ATSIRI KULIT JERUK NIPIS (Citrus aurantifolia) DALAM MENGHAMBAT PERTUMBUHAN BAKTERI Streptococcus agalactiae
}

\author{
Ajeng Shanaz Santya Putri ${ }^{\star 凶}$, Noorhamdani AS ${ }^{\star \star}$, Khuznita Dasa Novita**
}

\begin{abstract}
Abstrak
Minyak atsiri kulit jeruk nipis (Citrus aurantifolia) mempunyai efek antibakteri pada pertumbuhan Streptococcus agalactiae melalui penghancuran struktur sel bakteri. Penelitian ini bertujuan untuk membuktikan kemampuan antibakteri minyak atsiri kulit jeruk nipis dalam mencegah pertumbuhan bakteri Streptococcus agalactiae secara in vitro dan mengetahui konsentrasi hambat minimum yang diperlukan. Desain penelitian yang digunakan adalah experimental post test only group menggunakan metode difusi sumuran. Tujuh konsentrasi berbeda dari minyak atsiri (0\%; 3,125\%; 6,25\%; $12,5 \% ; 25 \% ; 50 \% ; 100 \%)$ digunakan dalam penelitian ini. Zona hambat yang didapat kemudian diukur menggunakan jangka sorong. Hasil penelitian ini menunjukkan bahwa kenaikan konsentrasi minyak atsiri kulit jeruk nipis berbanding lurus dengan bertambahnya diameter zona hambat di sekitar sumuran. Nilai konsentrasi hambat minimum (KHM) minyak atsiri kulit jeruk nipis didapat pada konsentrasi 25\%. Uji korelasi Spearman menunjukkan korelasi kuat dan signifikan $(r=0,799, p=0,000)$, dan uji komparasi Kruskall Wallis menunjukkan adanya perbedaan yang signifikan antar rerata tiap kelompok $(p=0,000)$. Dari percobaan ini, bisa disimpulkan apabila minyak atsiri kulit jeruk nipis dapat mencegah pertumbuhan Streptococcus agalactiae secara in vitro pada konsentrasi $25 \%$.
\end{abstract}

Kata kunci: kulit jeruk, minyak atsiri, Streptococcus agalactiae

\section{IN VITRO ANTIBACTERIAL ASSAY OF LIME (Citrus aurantifolia) PEEL ESSENTIAL OIL IN INHIBITING Streptococcus agalactiae GROWTH}

\begin{abstract}
Essential oil of lime peel (Citrus aurantifolia) has antibacterial effect against Streptococcus agalactiae by destroying the bacterial cell structure. The objective of this research was to prove the antibacterial activity of the essential oil of lime peel against the growth of Streptococcus agalactiae bacteria in vitro and to determine the required minimum inhibitory concentration. The research design used was an experimental post test only group with the well diffusion method. This study used different concentrations of essential oil $(0 \%$; $3.125 \% ; 6.25 \% ; 12.5 \% ; 25 \% ; 50 \% ; 100 \%)$. The inhibition zone was then measured using a Vernier scale. Results showed that the increase of concentration of essential oil of lime peel was directly proportional to the increase of the inhibition zone diameter around the well. The minimum inhibitory concentration (KHM) of essential oil of lime peel was $25 \%$. Spearman's correlation test showed a strong and significant correlation $(r=0.799, p=0.000)$, and the Kruskall Wallis comparison test showed a significant difference between the means of each group $(p=0.000)$. It can be concluded that lime peel essential oil can inhibit the growth of Streptococcus agalactiae in vitro at a concentration of $25 \%$.
\end{abstract}

Keywords: essential oils, lime peel, Streptococcus agalactiae

* Jurusan Pendidikan Dokter, Fakultas Kedokteran, Universitas Brawijaya

** Departemen Mikrobiologi, Fakultas Kedokteran, Universitas Brawijaya

${ }^{* * *}$ Departemen Kedokteran Keluarga, Fakultas Kedokteran, Universitas Brawijaya

『E-mail: ajengshanaz@student.ub.ac.id 


\section{Pendahuluan}

Streptococcus agalactiae atau Streptokokus Grup B (SGB) adalah patogen penting dalam tubuh manusia yang berkolonisasi di traktus urogenital dan gastrointestinal bagian bawah dari 40\% wanita sehat berusia produktif, sehingga dapat menimbulkan sepsis serta meningitis pada neonatus. Sepsis adalah salah satu kondisi yang dapat mengancam nyawa bayi. Pada tahun 2015, berdasarkan data dari 26 negara menunjukkan prevalensi global sepsis pada unit perawatan intensif anak sebesar $8,2 \%$. Disebutkan juga bahwa rata-rata usia sepsis tiga tahun dengan infeksi terbanyak terdapat pada sistem respirasi (40\%). Di Indonesia sendiri angka kejadian sepsis neonatorum dilaporkan sebesar $8,7 \%$ hingga $30,29 \%$ dengan angka kematian $11,56 \%$ hingga $40,9 \%{ }^{1}$

Selain itu, Streptococcus agalactiae juga dapat menginfeksi orang tua dan pasien dewasa dengan masalah imun. Seperti bakteri gram positif lainnya, Streptococcus agalactiae dapat membentuk struktur tiga dimensi seperti biofilm yang dapat meningkatkan kemampuannya untuk berkolonisasi dan bertahan hidup. ${ }^{2}$

Jeruk adalah salah satu herbal paling efektif dalam obat tradisional yang tergolong dalam genus Citrus dan famili Rutaceae. Genus Citrus atau jeruk adalah genus asli area tropis dan subtropis di Asia. Anggota genus ini dikenal memiliki banyak metabolit sekunder yang aktif secara biologis seperti flavonoid, limonoid, furamin dan furanokumarin, sterol, minyak atsiri, asam organik, serta alkaloid. Banyak spesies jeruk diakui karena aktivitas fisiologi dan farmakologi meliputi aktivitas antimikroba, antioksidan, antikanker, antiinflamasi, serta aktivitas hipo-glikemik. ${ }^{3}$

Berdasarkan kandungannya, jeruk nipis (Citrus aurantifolia) terutama minyak atsiri yang dapat diambil dari kulitnya berpotensi untuk menjadi antibakteri. Walaupun telah banyak penelitian yang menguji efek minyak atsiri jeruk nipis, sangat sedikit penelitian yang menggunakan minyak atsiri dari bagian kulitnya. Selain itu, masih belum ada penelitian yang menguji kemampuan anti-bakteri milik minyak atsiri kulit jeruk nipis secara spesifik terhadap bakteri Strepto-coccus agalactiae serta konsentrasi hambat minimum yang diperlukan. Kulit jeruk nipis seringkali menjadi limbah yang dibuang, namun masih ada manfaat dari kulit jeruk nipis ini. Oleh karena itu, peneliti ingin mengetahui kemampuan antibakteri minyak atsiri kulit jeruk nipis dalam mencegah pertumbuhan bakteri Streptococcus agalactiae secara in vitro.

\section{Bahan dan Metode}

\section{Desain dan Metode Penelitian}

Dalam penelitian ini digunakan rancangan penelitian eksperimental laboratoris dengan desain penelitian post-test only control group design serta memakai metode difusi sumuran (well diffusion test) guna melihat efektivitas minyak atsiri kulit jeruk nipis sebagai antibakteri terhadap Streptococcus agalactiae secara in vitro. Metode yang digunakan dalam penelitian ini dilakukan untuk menentukan kadar hambat minimal (KHM) berdasarkan area hambat yang terbentuk di sekitar sumuran. Variabel bebas dalam penelitian ini adalah konsentrasi minyak atsiri kulit jeruk mulai dari $0 \%, 125 \%, 6,25 \%, 12,5$ $\%, 25 \%, 50 \%, 100 \%$.

\section{Isolat Bakteri Streptococcus agalactiae}

Sampel bakteri Streptococcus agalactiae diambil dari stok kultur milik Rumah Sakit Umum Daerah Dr. Saiful Anwar Malang.

Identifikasi Bakteri Streptococcus agalactiae Pewarnaan Gram

Dilakukan dengan mengambil koloni Streptococcus agalactiae dengan ose dari nutrient agar ke object glass yang sebelumnya telah diberi tanda lingkaran. 
Kemudian menunggu sediaan sampai kering, dan difiksasi di atas api bunsen, dan diayunkan sebanyak 3-5 kali. Setelah itu, diteteskan larutan kristal violet, larutan lugol, larutan alkohol 96\%,serta larutan safranin. Setelah kering, diamati di bawah mikroskop menggunakan perbesaran lensa objektif 100x dengan minyak imersi. ${ }^{5}$

\section{Uji Katalase}

Suspensi bakteri yang diduga koloni Streptococcus agalactiae diambil dengan ose steril lalu diusapkan ke object glass. Setelah itu, diteteskan hidrogen peroksida $3 \%$ di atas preparat dan diamati pembentukan buih/ gelembung. Katalase positif ditunjukkan dengan terbentuknya gelembung. ${ }^{6}$

\section{Uji VITEK ${ }^{\circledR} 2$}

Vitek merupakan metode uji bakteri terbaru yang memiliki 3 tahap pemeriksaan, yaitu persiapan serta pembakuan atau standarisasi kekeruhan inokulum, kemudian memasukkan data dengan sistem barcode, dan memasukkan kartu ke dalam alat. Kemudian semua tahapan mulai dari inokulasi, inkubasi, pembacaan, validasi, dan interpretasi hasil akan dilakukan secara otomatis oleh alat. Hasil pemeriksaan bisa berupa rekam cetak (print-out) otomatis, sedangkan kartu identification/antimicroba sensitivity test (ID/AST) oleh sistem akan secara otomatis akan dibuang ke tempat sampah. Hasil pemeriksaan ini juga bisa langsung terhubung dengan Laboratory Information System (LIS). ${ }^{7}$

\section{Uji Hemolisis}

Pengujian terhadap patogenisitas Streptococcus agalactiae dilakukan pada blood agar plate (BAP). Koloni Streptococcus agalactiae diambil dengan metode gores menggunakan ose dan ditanam di media yang telah disediakan, kemudian diinkubasi selama 24-48 jam. Streptococcus agalactiae ditandai dengan kemampuan melisiskan sel darah merah yang dapat dilihat dengan terbentuknya zona bening di sekitar koloni pada media BAP. 8

\section{Penyulingan Minyak Atsiri Kulit Jeruk Nipis}

Kulit jeruk nipis diperoleh dari Simplisia

Medika Batu dan kemudian dilakukan penyulingan minyak atsiri di Institut Atsiri Universitas Brawijaya. Minyak atsiri kulit jeruk nipis yang digunakan dibuat dari kulit jeruk nipis sebanyak 1,140 kilogram. Kulit jeruk nipis yang telah dipisahkan dari isinya, kemudian dipotong kecil-kecil, dicuci, dan diangin-anginkan. Kemudian dilakukan penimbangan ulang untuk mengetahui persentase rendemen dari minyak yang dihasilkan. Setelah itu, dilakukan destilasi uap selama 6 jam pada suhu $98^{\circ} \mathrm{C}$. Cairan yang keluar dari kondensor didiamkan selama 24 jam untuk memisahkan minyak dan air. Lapisan air dibuang dan lapisan minyak atsiri diambil lalu ditambahkan dengan $\mathrm{Na}_{2} \mathrm{SO}_{4}$ untuk menyerap akuades yang masih terdapat dalam minyak atsiri. Kemudian ditentukan persentase rendemen dan massa jenis minyak serta minyak atsiri dianalisis dengan metode GC-MS. ${ }^{4}$

\section{Uji Aktivitas Antibakteri Minyak Atsiri}

Uji aktivitas antibakteri menggunakan Brain Heart Infusion Agar (BHIA) yang sudah padat, lalu dibuat lubang menggunakan blue tip sebanyak 7 lubang. Pada penelitian ini dgunakan 7 konsentrasi yaitu $0 \%$; $3,125 \% ; 6,25 \% ; 12,5 \% ; 25 \%$; $50 \%$; dan $100 \%$ serta dilakukan pengulangan sebanyak 4 kali. Konsentrasi minyak atsiri $0 \%$ adalah kelompok kontrol bakteri yang diberikan larutan $\mathrm{NaCl}$ tanpa minyak atsiri. Masing-masing konsentrasi ini dimasukkan ke dalam lubang yang berbeda. Lalu dilakukan inkubasi di suhu $37{ }^{\circ} \mathrm{C}$ selama 18 hingga 24 jam untuk kemudian diukur diameter area hambat yang terbentuk di sekitar sumuran. ${ }^{9}$ 
Hasil

\section{Hasil Identifikasi Bakteri}

Hasil pengamatan mikroskop menunjukkan bentukan bulat tersusun seperti rantai berwarna ungu yang menunjukkan bahwa bakteri merupakan Streptococcus Gram positif seperti yang terlihat pada Gambar 2a.

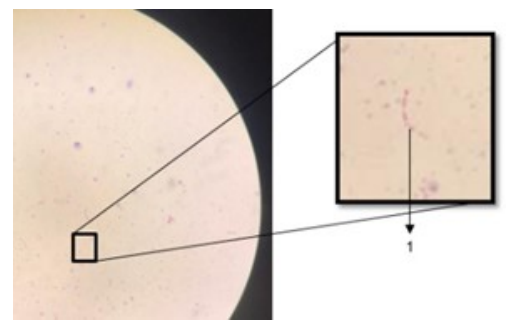

Gambar 2a. Bakteri Streptococcus agalactiae merupakan Streptococcus Gram positif

Keterangan: 1. Bakteri berbentuk kokus (bulat) yang tersusun seperti strepto (rantai)

\section{Uji Katalase}

Setelah ditetesi hidrogen peroksida 3\%, tidak timbul gelembung, maka dapat disimpulkan bakteri bersifat katalase negatif yang ditunjukkan pada Gambar 2b.

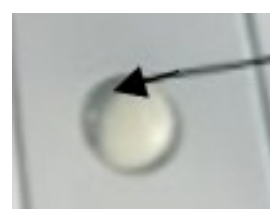

Gambar 2b. Uji katalase menunjukkan tidak terbentuk gelembung yang menandakan katalase negatif (tanda panah)

\section{Uji Hemolisis}

Uji hemolisis Streptococcus agalactiae pada BAP yang diinkubasi di suhu $37^{\circ} \mathrm{C}$ selama 18 hingga 24 jam menunjukkan area beta hemolytic seperti pada Gambar 2c.

\section{Uji VITEK ${ }^{\circledR} 2$}

Uji Vitek pada Gambar 2 menunjukkan bahwa bakteri adalah Streptococcus agalactiae.

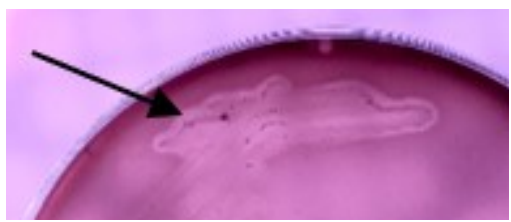

Gambar 2c. Terlihat zona bening di sekitar koloni bakteri yang mendekati warna dasar, menunjukkan beta-hemolisis (tanda panah)

\begin{tabular}{ll|l|}
\hline Analysis Time: & 7.82 hours & Status: Final \\
\hline 95\% Probability & Stroptococcus agalactiae \\
Bionumber: & 051410361717671 & \\
\hline
\end{tabular}

Gambar 2d. Hasil uji VITEK ${ }^{\circledR} 2$

Uji Aktivitas Antibakteri Minyak Atsiri Kulit Jeruk Nipis

Hasil uji menunjukkan bahwa minyak atsiri kulit jeruk nipis sensitif pada konsentrasi $25 \%$ dalam mencegah pertumbuhan bakteri Streptococcus agalactiae. Hasil pengamatan dan pengukuran diameter zona hambat ditunjukkan pada Gambar 2 dan Tabel 1.

\section{Analisis Data}

Uji normalitas menggunakan Kolmogorov-Smirnov menunjukkan bahwa data terdistribusi normal $(p>0,05)$. Kemudian dilakukan uji homogenitas Levene yang menunjukkan bahwa data tidak bervariasi homogen ( $p$ $<0,05$ ). Analisis data dilanjutkan dengan uji post hoc metode Mann-Whitney untuk melihat signifikansi setiap kelompok data terhadap kelompok lainnya (Tabel 2). Uji korelasi rank Spearman mendapatkan nilai $p=0,000$ yang bermakna adanya hubungan yang signifikan antara konsentrasi minyak atsiri dengan diameter zona hambat yang terbentuk, dengan nilai korelasi $(r)=0,799$.

Berikutnya adalah uji regresi linear, didapatkan nilai $a=1,108 b=0,263$ dan nilai $R$ square yang didapatkan adalah sebesar 0,714 . 


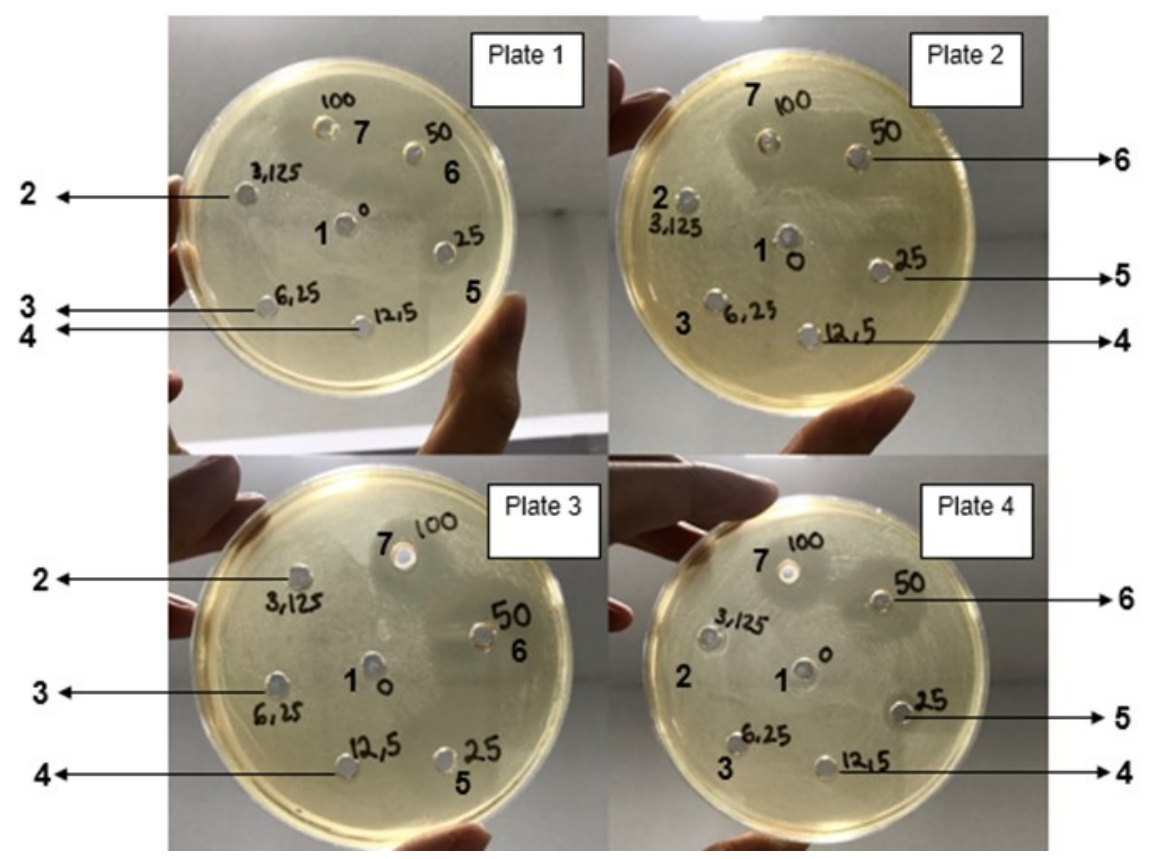

Gambar 3. Aktivitas antibakteri minyak atsiri kulit jeruk nipis pada pertumbuhan Streptococcus agalactiae

Keterangan: 1. Minyak atsiri kulit jeruk nipis konsentrasi 0\%, 2. konsentrasi 3,125\%, 3. konsentrasi 6,25\%,

4. Konsentrasi $12,5 \%$, 5. Konsentrasi 25\%, 6. Konsentrasi 50\%, 7. Konsentrasi 100\%

Tabel 1. Hasil pengukuran diameter zona hambat minyak atsiri kulit jeruk nipis pada pertumbuhan Streptococcus agalactiae

\begin{tabular}{lllll}
\hline \multirow{2}{*}{ Perlakuan } & \multicolumn{4}{c}{ Diameter Zona Hambat (mm) } \\
\cline { 2 - 5 } & \multicolumn{1}{c}{ I } & \multicolumn{1}{c}{ II } & III & IV \\
\hline Minyak atsiri $0 \%$ (Kontrol -) & 0 & 0 & 0 & 0 \\
Minyak atsiri $3,125 \%$ & 0 & 0 & 0 & 0 \\
Minyak atsiri $6,25 \%$ & 0 & 0 & 0 & 0 \\
Minyak atsiri $12,50 \%$ & 0 & 0 & 0 & 0 \\
Minyak atsiri $25,00 \%$ & 11 & 17 & 22 & 10 \\
Minyak atsiri $50,00 \%$ & 25 & 19 & 24 & 21 \\
Minyak atsiri $100,00 \%$ & 28 & 21 & 18 & 22 \\
\hline
\end{tabular}

Tabel 2. Hasil uji Mann-Whitney

\begin{tabular}{lccccccc}
\hline Konsentrasi & $0 \%$ & $3,125 \%$ & $6,25 \%$ & $12,5 \%$ & $25 \%$ & $50 \%$ & $100 \%$ \\
\hline $0 \%$ & & - & - & - & + & + & + \\
$3,125 \%$ & - & & - & - & + & + & + \\
$6,25 \%$ & - & - & & - & + & + & + \\
$12,5 \%$ & - & - & - & & + & + & + \\
$25 \%$ & + & + & + & + & & + & + \\
$50 \%$ & + & + & + & + & + & & - \\
$100 \%$ & + & + & + & + & + & - & \\
\hline
\end{tabular}

Keterangan: $\operatorname{Sig}(+)=p<0,05,(-), p>0,05$ 


\section{Pembahasan}

Pada penelitian ini didapatkan bahwa minyak atsiri kulit jeruk nipis konsentrasi $25 \%$ mampu menghambat pertumbuhan bakteri Streptococcus agalactiae yang bersifat kuat melalui pengamatan pada diameter zona hambat (>20-30 mm). ${ }^{10}$ Penelitian yang dilakukan oleh Safitri et al. (2017) juga menunjukkan bahwa bakteri Streptococcus agalactiae dapat dihambat menggunakan ekstrak buah mahkota buah (Phaleria macrocarpa L.) pada konsentrasi 50\% menghasilkan diameter zona hambat sebesar $10 \mathrm{~mm} .{ }^{11}$ Selain itu, penelitian yang dilakukan oleh Vajriana (2013) membuktikan bahwa minyak atsiri kulit jeruk nipis mampu mencegah tumbuhnya bakteri Staphylo-coccus aureus pada konsentrasi 30\%.12 Namun, hasil penelitian oleh Ly (2017) menunjukkan bahwa minyak atsiri kulit jeruk nipis mampu mencegah tumbuhnya bakteri Streptococcus pyogenes pada konsentrasi $25 \%$ dengan diameter zona hambat sebesar $8,4 \mathrm{~mm} .{ }^{13}$ Berbeda dengan hasil penelitian ini yang menunjukkan rata-rata diameter zona hambat sebesar $15 \mathrm{~mm}$ pada konsentrasi $25 \%$, maka pada penelitian yang dilakukan Yuwanda (2014) menunjukkan hasil konsentrasi bunuh minimum (KBM) pada konsentrasi minyak atsiri kulit jeruk nipis $0,3 \%$ pada bakteri Streptococcus mutans. ${ }^{14}$

Minyak atsiri kulit jeruk nipis dapat menghambat pertumbuhan bakteri karena di dalam minyak atsiri terdapat kandungan senyawa hidrokarbon teroksigenasi (fenol) yang bersifat hidrofobik dan dapat membelah lapisan lemak pada membran sel bakteri dan mitokondria yang membuat sel rusak. Hal ini kemudian membuat kebocoran luas dari sel bakteri yang berujung pada kematian sel. ${ }^{15}$ Terdapat beberapa keterbatasan dalam penelitian ini, di antaranya belum diteliti pengaruh waktu penyimpanan terhadap kandungan minyak atsiri serta potensi zat aktifnya dalam mencegah pertumbuhan bakteri.

\section{Kesimpulan}

Dari hasil penelitian disimpulkan bahwa minyak atsiri kulit jeruk nipis dapat mencegah tumbuhnya bakteri Streptococcus agalactiae dengan konsentrasi hambat minimum (KHM) 25\% dengan rata-rata diameter zona hambat yang tergolong kuat $>20-30$ $\mathrm{mm})$.

\section{Daftar Pustaka}

1. Wulandari A, Martuti $S$, Kaswadi $P$. Perkembangan Diagnosis Sepsis pada Anak. Sari Pediatr. 2018; 19(4):237. Microbiol. 2015; 5(FEB):2013-6.

2. Rosini R, Margarit I. Biofilm Formation by Streptococcus agalactiae: Influence of Environmental Conditions and Implicated Virulence Factor. Front Cell Infect Microbiol. 2015; 5(FEB):2013-6.

3. Saeb S, Amin M, Seyfi Gooybari R, Aghel N. Evaluation of Antibacterial Activities of Citrus limon, Citrus reticulata, and Citrus grandis Against Pathogenic Bacteria. Int J Enteric Pathog. 2016; 4 (4):11-5. DOI: http:// dx.doi.org/10.15171/ijep.2016.13.

4. Wibaldus, Jayuska $A$, Ardiningsih $P$. Biokativitas Minyak Atsiri Kulit Buah Jeruk Nipis (Citrus aurantifolia) terhadap Rayap Tanah (Coptotermes sp.). J Kim Khatulistiwa. 2016; 5(1):44-51.

5. Noorhamdani, Dzen S, Winarsih S, Roekistiningsih S, Sumarno I. Bakteriologi Medik. Malang: International Research and Development for Human Beings. 2003. P. 108-109.

6. Hayati LN, Tyasningsih W, Praja RN, Chusniati S, Yunita MN, Wibawati PA. Isolasi dan Identifikasi Staphylococcus aureus pada Susu Kambing Peranakan Etawah Penderita Mastitis Subklinis di Kelurahan Kalipuro, Banyuwangi. J Med Vet. 2019; 2(2):76. 
7. Prihartini, Aryati, Hetty. Identifikasi Cepat Mikroorganisme Menggunakan Alat VITEK-2. Indones J Clin Pathol Med Lab. 2018; 13(3):129.

8. Sukmadewi DKT, Anas I, Widyastuti R, Cintaresmini A. Uji Fitopatogenitas, Hemolisis serta Kemampuan Mikrob dalam Melarutkan Fosfat dan Kalium. J IImu Tanah dan Ling. 2017; 19(2):68-73.

9. Särndal CE, Swensson B, Wretman J. Model Assisted Survey Sampling. Springer Science \& Business Media. 2003.

10. Morales $G$, Sierra $P$, Mancilla, Parades A, Loyola LA, Gallardo O, Borquez J. Secondary Metabolites from Four Medicinal Plants from Northern Chile, Antimicrobial Activity, and Biotoxicity against Artemia salina. Journal Chile Chem. 2003; 48:13-18. D OI: $10.4067 /$ S 0717 97072003000200002.

11. Safitri L, Susilorini T, Surjowardojo P. Evaluasi Aktivitas Antimikroba (Streptococcus agalactiae) Menggunakan Exstrak Buah Mahkota Buah (Phaleria macrocarpa L.) dengan
Pelarut yang Berbeda. J IImu dan Teknol Has Ternak. 2017; 12(1):8-15.

12. Vajriana E. Aktivitas Antibakteri Minyak Atsiri Kulit Buah Jeruk Nipis (Citrus aurantifolia) terhadap Isolat Staphylococcus aureus Secara In Vitro. (Skripsi). Aceh: Fakultas Kedokteran, Universitas Syiah Kuala. 2013.

13. Ly WM. Uji Aktivitas Antibakteri Minyak Atsiri Kulit Buah Jeruk Nipis (Citrus aurantifolia Swingle) terhadap Streptococcus pyogenes. (Skripsi). Surabaya: Fakultas Kedokteran, Universitas Katolik Widya Mandala. 2017.

14. Yuwanda R. Pengaruh Minyak Atsiri Kulit Jeruk Nipis (Citrus aurantifolia) terhadap Pertumbuhan Bakteri Streptococcus mutans. (Skripsi). Malang: Fakultas Kedokteran Gigi, Universitas Brawijaya. 2014.

15. Pratiwi D, Suswati I, Abdullah M. Efek Antibakteri Ekstrak Kulit Jeruk Nipis (Citrus aurantifolia) terhadap Salmonella Typhi Secara In Vitro. Saintika Medika: Jurnal IImu Kesehatan dan Kedokteran Keluarga. 2013; 9(2):110-115. 